\title{
Literature review on Health Knowledge Management in the last 10 years (2009-2019)
}

\author{
Albérico Manuel Fernandes Travassos Rosário ${ }^{1}$, Filipa Isabel de Almeida Fernandes Vilaça², \\ Ricardo Raimundo ${ }^{3}$ and Rui Manuel Nunes $\mathrm{Cruz}^{4}$ \\ ${ }^{1}$ GOVCOPP, ESGTS - IPSantarém, Portugal \\ ${ }^{2}$ IPAM-The Marketing School, Portugal \\ ${ }^{3}$ IPAM-The Marketing School, Portugal \\ ${ }^{4}$ UnidCom-IADE, Universidade Europeia, Portugal \\ alberico.rosario@esg.ipsantarem.pt \\ filipa.fernandes@universidadeeuropeia.pt \\ Ricardo.raimundo@universidadeeuropeia.pt \\ rui.cruz@universidadeeuropeia.pt \\ 1orcid.org/0000-0003-4793-4110 \\ 2orcid.org/0000-0002-7200-8736 \\ ${ }^{3}$ orcid.org/0000-0002-7022-9447 \\ ${ }^{4}$ orcid.org/0000-0002-5773-6049
}

\begin{abstract}
Health care institutions $(\mathrm{HCl}$ in further text) are in constant interplay with their context, generating ensuing opportunities and threats. Knowledge management has been paramount when it comes to integrating state-of-art technologies in order to improve system efficiency and decision processes in hospital management outputs. Thus, it is pivotal to explain the role of knowledge management in hospital management. Research of peer-reviewed articles published from 2009 to 2019, and obtained via the Scopus database, was carried out based on two key subjects, 'knowledge management' and 'health care institutions'. The research was performed through a descriptive, quantitative and qualitative analysis of the most cited 47 scientific articles found in the SCOPUS database. We conclude that 'knowledge management' (KM in further text) has become an important research area in terms of $\mathrm{HCl}$ management. The article identifies the central themes in $\mathrm{KM}$ research in $\mathrm{HCl}$. However, the area on $\mathrm{KM}$ literature is highly fragmented, requiring development. Based on an analysis of the collected literature, we identified the key research themes and resulting development patterns, namely, the integration and interoperability of knowledge from different sources into a single platform, occupational safety, the need to ascertain quality and pertinent information among general web information, culture and social behaviour and data security. We posit that KM effectively facilitates the utilization of healthcare information resources and management decision making in hospitals.
\end{abstract}

Keywords: knowledge management, health care institutions

\section{Introduction}

Knowledge management in health care institutions has emerged as an important stream of research at the interface of technological innovations and health systems. If we consider knowledge management as a set of technologies and processes whose objective is to support the creation, transfer and application of knowledge in organizations (Girard and Girard, 2015), we would enhance the link between KM and the idiosyncrasies of $\mathrm{HCl}$. Our research goal is focused on examining the interplay between those two branches of knowledge on literature, and the ensuing findings aim at expanding the literature on the relationship between $\mathrm{KM}$ and $\mathrm{HCl}$ by highlighting the main trends and themes.

Although $\mathrm{KM}$ in $\mathrm{HCl}$ research has gained momentum lately while providing insights into knowledge sharing in health communities, it is important to reinforce results from related research in health and knowledge management, relevant to both health informatics literature and health community management (e.g., Yan et al., 2016; Tuarob et al., 2013; Mafabi et al., 2017; Chandra and Loosemore, 2011; Gu et al., 2019). The literature in the topic is diverse and fragmented, hindering the development of the subject as a promising research area. In this paper, an analysis of the ' $\mathrm{KM}$ in $\mathrm{HCl}^{\prime}$ literature is performed based on citations of 47 central articles in order to examine the development and identify research themes and developmental patterns of ' $\mathrm{KM}$ in $\mathrm{HCl}^{\prime}$ research (e.g., Yan et al., 2016; Tuarob et al., 2013; Mafabi et al., 2017; Chandra and Loosemore, 2011; Gu et al., 2019). 
This paper addresses the sparse literature on those topics, and related intersections between the $\mathrm{KM}$ and $\mathrm{HCl}$ best practices regarding some central themes that emerged from a Scopus database literature survey. Hence, the focus of this literature review (LR in further text) is on ' $\mathrm{KM}$ in $\mathrm{HCl}^{\prime}$ most cited issues.

Based on the literature review, this article aims to clarify the knowledge management in Health in the last 10 years and the main contributions and implications, specifically, to know to what extent issues related to knowledge sharing, information dissemination and artificial intelligence, identifying paths and themes for the future focusing on the following aspects: Integration and interoperability of knowledge; which deal with facilitating communication, cooperation, and collaboration within an organization (verdanat, 2009); Artificial Intelligence (AI) in knowledge management systems: Al can extend socially-based conceptual KM tools through supporting human agents manage most forms of knowledge (Sangozi, Guzman and Busch, 2017), interaction of $\mathrm{KM}$ with AI makes possible the development of filtering tools and pre-analysis of the information that appear as a reply to the expectations to extract resulted optimized of databases and open and not-structuralized source, as the Internet (Hoeschl and Barcellos, 2006); and Ubiquitous Technologies: smart organizations do not rely on knowledge production, but focus on knowledge integration instead (Kaivo-Oja et al, 2015).

The document is divided into three parts. The first presents the research methodology illustrating the various steps followed in database segmentation, as well as a review of the literature on health knowledge management in the last 10 years (2009-2019). The second part presents the results with a long list of considerations and findings from the articles investigated and finally a third part integrates a discussion and conclusions from the research.

\section{Methodology}

Knowledge production requires deep understanding and domain of the concepts related to the subject to be researched. Comprehensive literature review is a sine qua none condition to better understand how the problem has been investigated and dealt with. Literature review helps defining the problem and aids in the search for new investigation techniques, by identifying methodologies that have not yet been tested.

Having as subject the analysis of different marketing strategies for product development, a compilation of peerreviewed literature took place. Employing this method allows for a broad collection of the different product development strategies, as well as it promotes a good understanding of how these have evolved throughout time, while identifying the researchers, peer-reviewed literature and the subject of the most relevant peerreviewed articles (Rosário and Cruz, 2019; Sacavém, et al., 2019; Rosário, 2018; Willett, 2007 Granovsky, 2001). The revision and compilation of peer-reviewed literature allows summarising the main questions and results obtained in these studies, whereby these can have conceptual or empiric character. The main limitation of our methodology lies on the fact that the gathering of information is carried out through slow and extensive manual work. Modern internet services and databases allow easy and fast access to documents in electronic format, helping the dissemination of peer-reviewed literature.

In this context, the revision of peer-reviewed literature consists on the 1) identification, 2) selection, 3) analysis, and 4 ) summarization of the existent knowledge about a specific theme, as per the method employed by Denyer and Tranfield (2009).

Making use of the above-mentioned method, we will 1) define the research purpose, 2) select the databases from which the information will be compiled from, 3) evaluate and select peer-reviewed literature, 4) analyse and summarise the findings, 5) present the results, and, 6) discussion and conclusion of the results obtained, this methodology will ensure that a broad reach, that is equally auditable and repeatable, while answering specific questions arising from this research (Rosário and Cruz, 2019; Sacavém, et al., 2019; Rosário, 2018). During March 2020, a survey and literature review on Health Knowledge Management in the last 10 years was carried out.

The survey was conducted in the Scopus database which according to Elsivier is the largest abstract and citation database of peer-reviewed literature: scientific journals, books and conference proceedings. 


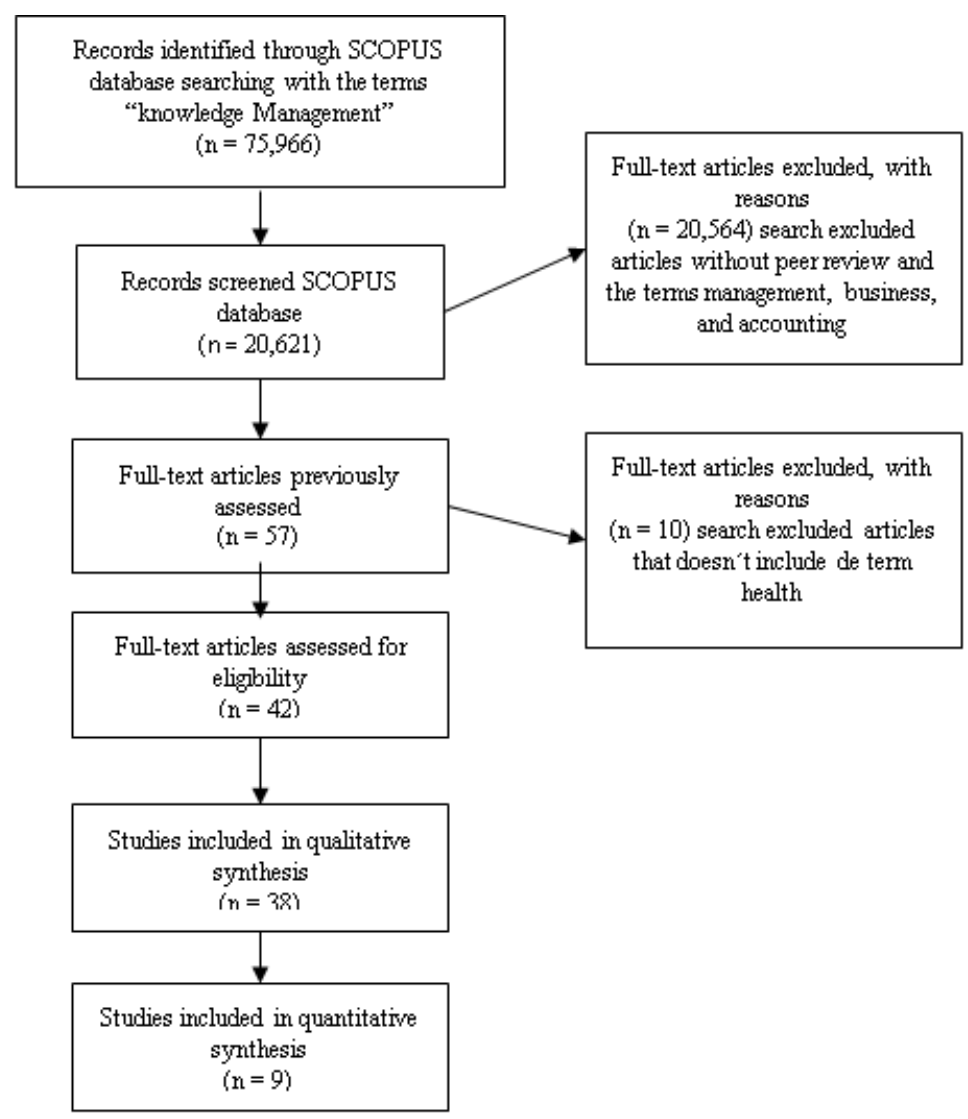

Figure 1: Segmentation criteria - adaptation from the PRISMA model (Mother et al, 2009)

For research purposes the topic "knowledge management" was initially used, obtaining 75,966 documents. Having then limited the search to the topics of business, management and accounting, several articles were eliminated and this segmentation retained a total of 20,621 documents. Finally, by restricting the latter to a new segmentation by delimiting it to the keyword "Health", a result of 57 documents was achieved. The final criteria to which these last articles were exposed included the peer review criteria for the time period between 2009 and 2019.

The final number of articles obtained is 42 , which constitutes the universe on which this research was focused. Figure 1, above placed constitutes an adaptation of the PRISMA model (Mother et al, 2009) and tries to illustrate the procedure described.

The found peer-reviewed literature makes use of different methods, with most of them being case studies and some quantitative research. When examining the methods and associated type of analysis, we found that 5 out of 47 articles focus on "individuals" or "communities" (Margerite, 2018; Tate et al., 2011; Gonçalves, Silveira and Rocha, 2011; Bratu, 2010; Yan et al., 2016; Warkulwiz, Paul and Mehta, 2014).

The remaining 42 articles focus on analysis at the organizational level. There is a clear emphasis on qualitative case study analysis ( 38 articles) as opposed to quantitative analysis ( 9 articles - Gu et al., 2019; Jimmy et al. 2019; Allerhand et al., 2018; Lagrosen, 2018; Yan et al., 2016; Sun, Huang and Chu, 2015; Koeling, Tate and Carroll, 2011; Emerencia et al., 2011 Farouk, Richardson and Santhapparaj, 2011).

\section{Results}

The most productive year for peer-reviewed articles on $\mathrm{KM}$ and $\mathrm{HCl}$, was 2011 with 18 publications (2019, 3; $2018,5 ; 2017,2 ; 2016,1 ; 2015,3 ; 2014,1 ; 2013,1 ; 2012,3 ; 2011,18) ; 2010,8 ; 2009,2)$. Graph 1, we can analyze the evolution of publications over the years. The articles were published as follows: 30 in conference papers, 15 articles and 2 reviews. 


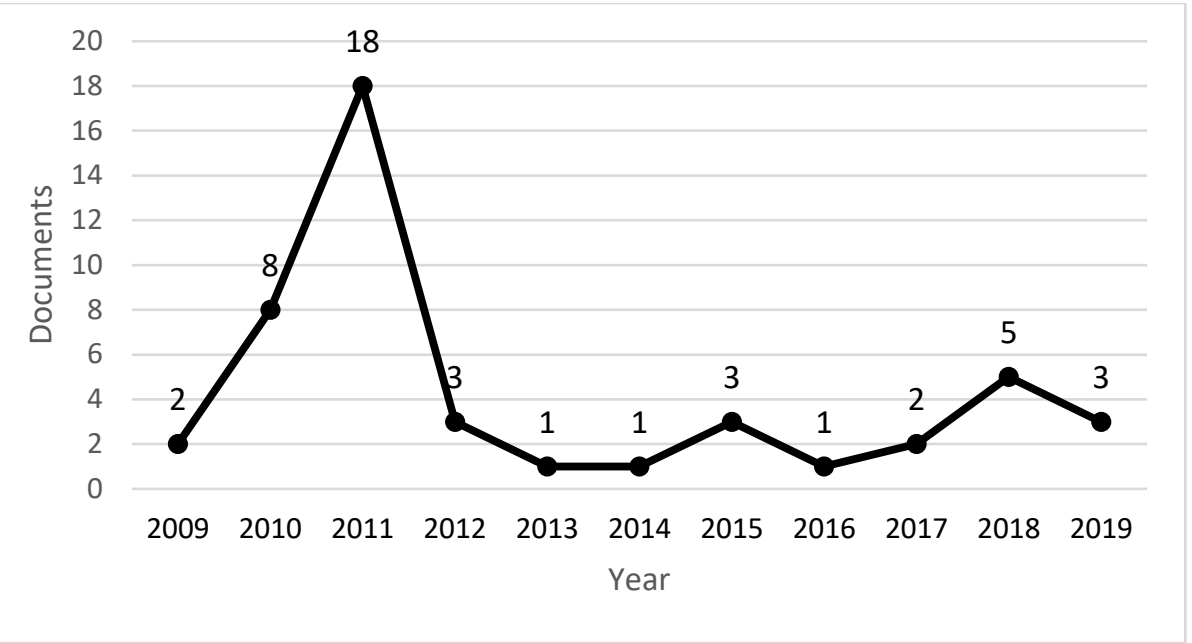

Figure 2: Documents by year

Table 1 summarises the Scimago Journal and Country Rank (SJR) impact factor, for the sources of publication of the collected peer-reviewed articles. SJR, Best Quartile and the $\mathrm{H}$ index per publication, are provided for each of the publication sources. Information and Management is the most quoted source, with 1,727 (SJR), a Q1 Best Quartile and an $\mathrm{H}$ index of 142 . Worth mentioning are are 4 newspapers from $\mathrm{Q} 1$ and 6 newspapers from Q2, 2 newspapers from Q3, 2 newspapers from Q4.

The International Conferences on Information and Knowledge Management Proceedings and Proceedings of The International Conference on Intellectual Capital Knowledge Management and Organisational Learning Icickm, have an SJR score of 0.519 and of 0.111 respectively. Conferences represent $33 \%$ of the publications.

Table 1: Scimago journal and country rank impact factor

\begin{tabular}{|c|c|c|c|}
\hline Title & SJR & $\begin{array}{c}\text { Best } \\
\text { Quartile }\end{array}$ & $H$ index \\
\hline International Conference on Information and Knowledge Management Proceedings & 0,519 & $-{ }^{*}$ & 102 \\
\hline $\begin{array}{l}\text { Business Transformation Through Innovation and Knowledge Management An } \\
\text { Academic Perspective Proceedings Of The 14th International Business Information } \\
\text { Management Association Conference Ibima } 2010\end{array}$ & 0 & $-*$ & 3 \\
\hline Information and Management & 1,727 & Q1 & 142 \\
\hline $\begin{array}{l}\text { Proceedings of The International Conference on Intellectual Capital Knowledge } \\
\text { Management and Organisational Learning Icickm }\end{array}$ & 0,111 & $-*$ & 3 \\
\hline Vine Journal of Information and Knowledge Management Systems & 0,362 & Q2 & 24 \\
\hline ACM Transactions on Information Systems & 0,550 & Q1 & 75 \\
\hline British Food Journal & 0,485 & Q2 & 69 \\
\hline Business Information Review & 0,231 & Q2 & 14 \\
\hline Communication et Management & 0,480 & Q2 & 31 \\
\hline Construction Management and Economics & 0,777 & Q1 & 81 \\
\hline Development and Learning in Organisations & 0,138 & Q4 & 13 \\
\hline Engineering Construction and Architectural Management & 0,580 & Q1 & 49 \\
\hline $\begin{array}{l}\text { Innovation and Knowledge Management A Global Competitive Advantage Proceedings } \\
\text { of the 16th International Business Information Management Association Conference } \\
\text { Ibima } 2011\end{array}$ & $-*$ & $-*$ & 2 \\
\hline International Conference on Management and Service Science Mass 2011 & $-{ }^{*}$ & $-{ }^{*}$ & 5 \\
\hline International Journal of Grid and Utility Computing & 0,462 & Q2 & 14 \\
\hline International Journal of Information Systems and Change Management & 0,130 & Q4 & 10 \\
\hline International Journal of Innovation Science & 0,185 & Q2 & 9 \\
\hline International Journal of Knowledge Management & 0,307 & Q3 & 19 \\
\hline International Journal of Technology Management & 0,502 & Q1 & 51 \\
\hline Lecture Notes in Business Information Processing & 0,243 & Q3 & 40 \\
\hline $\begin{array}{l}\text { Proceedings 3rd International Conference on Information Management Innovation } \\
\text { Management and Industrial Engineering Iciii } 2010\end{array}$ & $-*$ & $-*$ & 8 \\
\hline Proceedings of Institution of Civil Engineers Management Procurement and Law & 0,160 & Q3 & 8 \\
\hline Proceedings of the 4th IEEE Global Humanitarian Technology Conference Ghtc 2014 & $-{ }^{*}$ & $-{ }^{*}$ & 10 \\
\hline
\end{tabular}




\begin{tabular}{lccc}
\hline Title & SJR & $\begin{array}{c}\text { Best } \\
\text { Quartile }\end{array}$ & H index \\
\hline $\begin{array}{l}\text { Proceedings of the 6th Iberian Conference on Information Systems And Technologies } \\
\text { Cisti } 2011\end{array}$ & $-*$ & $-*$ & 8 \\
\hline
\end{tabular}

Note: $*$ data not available.

The subject areas covered by the 22 scientific articles were: Business, Management and Accounting (47); Decision Sciences (29); Computer Science (12); Engineering (8); Social Sciences (4); Mathematics (2); Agricultural and Biological Sciences; Economics, Econometrics and Finance (1).

The most cited article was the "Inter-organizational knowledge sharing system in the health sector: Physicians' perspective" by Al-Busaidi (2015), with 96 citations published in the International Journal of Knowledge Management, scoring 0.307 on SJR, with a Best Quartile Q3 and with an h-index 19, (2016, 2; 2017, 12; 2018, $26 ; 2019 ; 49$ 2020, 7).

Articles published in the International Journal of Knowledge Management newspaper focus on the study of the attitude of doctors towards the implementation of the interorganizational knowledge sharing system in the health sector. The case study was conducted in Oman.

Figure 2 shows the evolution of citations for articles published between 2009 and 2019. The number of citations dropped between 2013 and 2016, reaching a record of 73 citations in 2019.

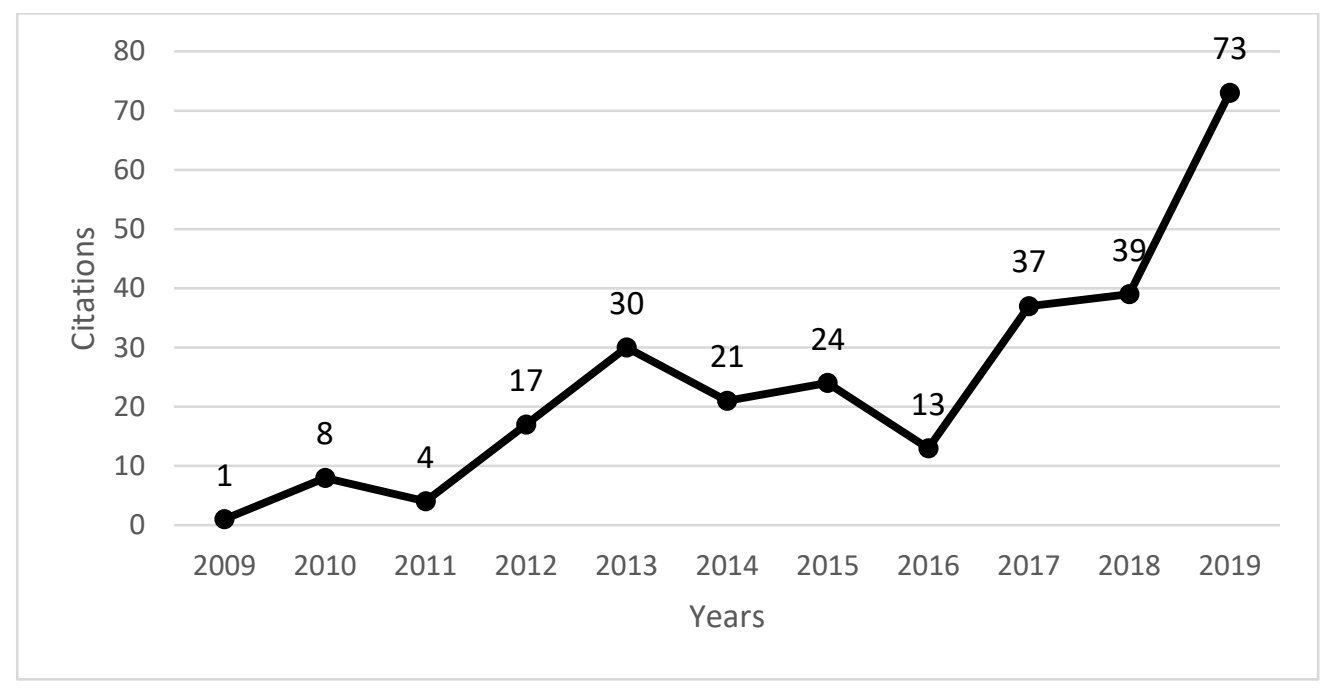

Figure 3: Evolution of citations between 2009 and 2019

The h-index was used to purchase the productivity and impact of the published work, based on the largest number of articles included that had at least the same number of citations. Of the documents considered for the h-index 8 , have been cited at least 8 times (Figure 3). 


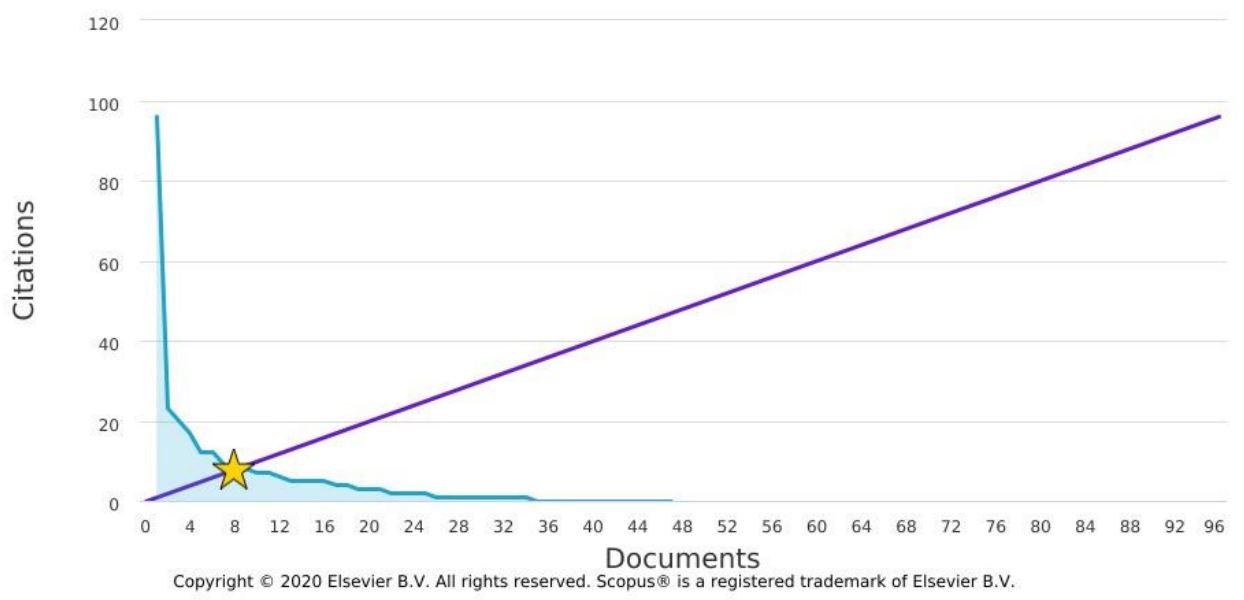

Figure 4: Documents h-index 8

Source: Scopus.

Appendix I analyzes the citations of all scientific articles from 2009 to 2019. 15 documents were not cited between 2009 - 2019 and in 2009, 1; 2010, 8; 2011, 4; 2012, 17; 2013, 30; 2014, 21; 2015, 24; 2016, 13; 2017, 37; 2018, 39; 2019, 73, a total of 267 times, 1 open Access and 46 with different types of access, divided as follows: Conference Paper (30); Article (15); Review (2) by subject area: Business, Management and Accounting (47); Decision Sciences (29); Computer Science (12); Engineering (8); Social Sciences (4); Mathematics (2); Agricultural and Biological Sciences (1); Economics, and Econometrics and Finance (1). Conference Paper 30, by subject área: Business, Management and Accounting (30); Decision Sciences (26); Computer Science (4); Engineering (3) and Mathematics (1).

Article 15, by subject area: Business, Management and Accounting (15); Computer Science (8); Engineering (5); Decision Sciences (3); Social Sciences (3); Agricultural and Biological Sciences (1) and Mathematics (1). Por último, Review 2, by subject área: Business, Management and Accounting (2); Economics, Econometrics and Finance (1); Social Sciences (1).

In Annex II, we analyzed the self-citation of documents during the period from 2010 to 2019, 9 documents were self-cited 20 times, the Service and dynamic integration oriented to health data models (2011), an article presented at the International Conference on Information and Knowledge Management, Proceedings was selfcited 4 times in 2913, 1 time in 2014, for a total of 5 in the period 2009-2019. The document Knowledge sharing in online health communities: a perspective on the social exchange theory of Yan et al. (2016) was the least selfcited 1 times in 2018.

Of the 47 scientific articles, 15 were never cited (Table 2), 4 of the non-cited articles were published in the Business Transformation Through Innovation and Knowledge Management an Academic Perspective Proceedings of The 14th International Business Information Management Association Conference Ibima 2010, the article Impacts of case-based health knowledge system in hospital management: The mediating role of group effectiveness published in Information and Management, the SJR 1,727, Best Quartile Q1 and H index 142 of 2019 was not mentioned during the period.

Table 2: Documents without citations during the period of 2009 and 2019

\begin{tabular}{|c|c|c|c|c|c|}
\hline Documents & Investigator & Title & SJR & $\begin{array}{l}\text { Best } \\
\text { Quartile }\end{array}$ & $\begin{array}{l}\mathrm{H} \\
\text { index }\end{array}$ \\
\hline $\begin{array}{l}\text { Impacts of case-based health } \\
\text { knowledge system in hospital ma } \\
\text {... }\end{array}$ & $\begin{array}{l}\text { Gu et al. } \\
(2019)\end{array}$ & Information and Management & 1,727 & Q1 & 142 \\
\hline
\end{tabular}




\begin{tabular}{|c|c|c|c|c|c|}
\hline Documents & Investigator & Title & SJR & $\begin{array}{l}\text { Best } \\
\text { Quartile }\end{array}$ & $\begin{array}{l}\mathrm{H} \\
\text { index }\end{array}$ \\
\hline $\begin{array}{l}\text { Health card retrieval for consumer, } \\
\text { health search an empírica ... }\end{array}$ & $\begin{array}{l}\text { Jimmy et al. } \\
\text { (2019) }\end{array}$ & $\begin{array}{l}\text { International Conference on } \\
\text { Information and Knowledge } \\
\text { Management, Proceedings }\end{array}$ & 0,519 & $-*$ & 102 \\
\hline $\begin{array}{l}\text { Briefing: Status of occupational } \\
\text { safety and health in GCC co ... }\end{array}$ & $\begin{array}{l}\text { Umar et al. } \\
\text { (2019) }\end{array}$ & $\begin{array}{l}\text { Proceedings of Institution of Civil } \\
\text { Engineers Management } \\
\text { Procurement and Law }\end{array}$ & 0,160 & Q3 & 8 \\
\hline $\begin{array}{l}\text { Place du knowledge management } \\
\text { dans les organisations de sant... }\end{array}$ & $\begin{array}{l}\text { Margueritte } \\
(2018)\end{array}$ & Communication Et Management & 0,480 & Q2 & 31 \\
\hline $\begin{array}{l}\text { The effects of workplace learning } \\
\text { on employee health }\end{array}$ & $\begin{array}{l}\text { Lagrosen and } \\
\text { Lagrosen } \\
(2018)\end{array}$ & $\begin{array}{l}\text { Proceedings of The International } \\
\text { Conference on Intellectual Capital } \\
\text { Knowledge Management and } \\
\text { Organisational Learning Icickm }\end{array}$ & 0,111 & $-*$ & 3 \\
\hline $\begin{array}{l}\text { A fuzzy association rule-based } \\
\text { knowledge management system } \\
\text { f... }\end{array}$ & $\begin{array}{l}\text { Tsang et al. } \\
\text { (2018) }\end{array}$ & $\begin{array}{l}\text { VINE Journal of Information and } \\
\text { Knowledge Management Systems }\end{array}$ & 0,362 & Q2 & 24 \\
\hline $\begin{array}{l}\text { Developing a knowledge strategy } \\
\text { for medical humanitarian cri ... }\end{array}$ & $\begin{array}{l}\text { Stoddart et } \\
\text { al. (2015) }\end{array}$ & $\begin{array}{l}\text { Proceedings of The International } \\
\text { Conference on Intellectual Capital } \\
\text { Knowledge Management and } \\
\text { Organisational Learning Icickm }\end{array}$ & 0,111 & $-*$ & 3 \\
\hline $\begin{array}{l}\text { Paying the price as firms edge } \\
\text { out talent: Knowledge can be }\end{array}$ & (2012) & $\begin{array}{l}\text { Development and Learning in } \\
\text { Organisations }\end{array}$ & 0,138 & Q4 & 13 \\
\hline $\begin{array}{l}\text { Developing quality scores for } \\
\text { electronic health records for ... }\end{array}$ & $\begin{array}{l}\text { Tate et al. } \\
\text { (2011) }\end{array}$ & $\begin{array}{l}\text { International Conference on } \\
\text { Information and Knowledge } \\
\text { Management, Proceedings }\end{array}$ & 0,519 & $-*$ & 102 \\
\hline $\begin{array}{l}\text { Occupational safety and health } \\
\text { committees: A channel for } \\
\text { knowledge creation in } \\
\text { malaysia? }\end{array}$ & $\begin{array}{l}\text { Farouk, } \\
\text { Richardson } \\
\text { and } \\
\text { Santhapparaj } \\
\text { (2011) }\end{array}$ & $\begin{array}{l}\text { Innovation and Knowledge } \\
\text { Management A Global } \\
\text { Competitive Advantage } \\
\text { Proceedings of the 16th } \\
\text { International Business } \\
\text { Information Management } \\
\text { Association Conference Ibima } \\
2011\end{array}$ & - * $^{*}$ & $-*$ & 2 \\
\hline $\begin{array}{l}\text { Research on the operation } \\
\text { mechanism of EHMS }\end{array}$ & $\begin{array}{l}\text { Xia, Zhao and } \\
\text { Qi (2010) }\end{array}$ & $\begin{array}{l}\text { Proceedings 3rd International } \\
\text { Conference on Information } \\
\text { Management Innovation } \\
\text { Management and Industrial } \\
\text { Engineering Iciii } 2010\end{array}$ & $-*$ & $-*$ & 8 \\
\hline $\begin{array}{l}\text { Assessing the quantitative } \\
\text { factors ofhealthcare services }\end{array}$ & $\begin{array}{l}\text { Cicea e tal. } \\
(2010)\end{array}$ & \multirow{4}{*}{$\begin{array}{l}\text { Business Transformation Through } \\
\text { Innovation and Knowledge } \\
\text { Management an Academic } \\
\text { Perspective Proceedings Of The } \\
\text { 14th International Business } \\
\text { Information Management } \\
\text { Association Conference Ibima } \\
2010\end{array}$} & \multirow{4}{*}{0} & \multirow{4}{*}{$-*$} & \multirow{4}{*}{3} \\
\hline $\begin{array}{l}\text { Evaluative indicators ofthe } \\
\text { health ofthe organisations of ... }\end{array}$ & $\begin{array}{r}\text { Mureşan and } \\
\text { Ivan (2010) }\end{array}$ & & & & \\
\hline $\begin{array}{l}\text { Insight into tunisian consumers' } \\
\text { mind-set towards healthines ... }\end{array}$ & $\begin{array}{r}\text { Lakhdar and } \\
\text { Bouslama } \\
(2010)\end{array}$ & & & & \\
\hline $\begin{array}{l}\text { Health politics and systems in } \\
\text { the European Union: Partícula ... }\end{array}$ & Bratu (2010) & & & & \\
\hline
\end{tabular}

Note: ${ }^{*}$ Data not available

The analysis is based on the total of 47 most cited articles, out of a Scopus search centred on the keywords 'KM'

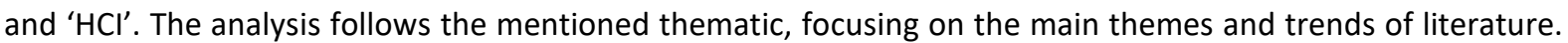
This leads to the identification of the key topics on the subject, discussed below.

The most recurrent theme in literature of $\mathrm{KM}$ in $\mathrm{HCl}$ is the integration and interoperability of knowledge from different sources into a single platform to ease its understanding by physicians. The goal is to achieve common understandings and semantics.

First, some research focused on methods to rank health cards, a domain-specific type of entity cards, for consumer health search (CHS) queries as small evidence exists to verify the electiveness of ranking methods for health cards in CHS (Jimmy et al. 2019). Others improve the delivery of the right information about the right 
patient at the point of care in order to attain a well-integrated and interoperable healthcare process, which is not easy to achieve due to the various differences in health data that cause enormous interoperability challenge (Taweel et al. 2011). Artificial Intelligence has been a challenge as well as case-based health knowledge management systems (CBHKS) have been extensively adopted in hospitals, including data-driven intelligent platforms that integrate 'state of the art' decision processes to improve hospital management outcomes (Gu et al. 2019).

Second, on the one hand, the need to unify distinct information for epidemiological research, as for example the General Practice Research Database (GPRD) with distinct coded information and an automatic method to extract significant information (Koeling, Tate, and Carroll, 2011), or on the other hand a framework for further improvement of existing methods of data quality assessment, using statistical pattern recognition techniques (Tate et al., 2011).

Third, some studies present systems such as a Semantic Web interoperability framework, which provides developers with software for semantic application deployment that allows interoperability (Lopes and Oliveira, 2011; Lytras, Sakkopoulos and De Pablos, 2009); while others focus on the need for semantic integration of different understandings through thematic content analysis (for example between designers and hospital constructors), to ensure optimal health outcomes by exploring the process of knowledge sharing during the project (Chandra and Loosemore, 2011) and also ensure efficiency, effectiveness and adaptability in $\mathrm{HCl}$ (Muresan and Ivan, 2010).

Fourth, research enhances the use of Information and Communication Technology (ICT) as a medium to integrate different information in different clinical points (Bouamrane and Mair, 2011), to build-up both the integrated equipment health management information system, structure and design (Zhang, Yu and Mu 2011) and the integration of the equipment health management system (e.g., between management theory and equipment health management) (Xia, Zhao and Qi, 2010).

Fifth, there is a research call for using compatible data formats and international terminology to ensure both the Interoperability between complex systems knowledge (Emerencia et al., 2011), data applications in healthcare (Tao et al., 2011) and the vast bio-medical knowledge to ensure an integrated electronic health systems infrastructure (Bouamrane and Tao, 2011). It has also been central to timely integrate disparate public health information systems from diverse geographic regions to better address emerging public health threats (e.g., the US Centers for Disease Control explored a decentralised information architecture using the Public Health Grid) (Boyd et al., 2011).

Finally, besides semantic and equipment integration, also the service integration is debated in literature. An ontology-driven framework was attempted to provide knowledge management for data of different modalities (e.g., by remote services in supporting multidisciplinary meetings that take place during breast cancer) (Dupplaw, et al., 2009). Furthermore, it is frequent to discuss the interoperability and integration of knowledge issue in less favoured contexts. In particular, in terms of insurance system with respect to coherent operation of social health insurance systems that support economic systems (Bratu, 2010); the focused crawling technique in the area of Information retrieval in specific search engines for health in non-representative languages (Pryiatam, 2012); and the need to share knowledge effectively with Community Health Workers (CHWs) within less favoured communities of low technological level (Warkulwiz, Paul and Mehta., 2014).

Other recurrent issue is occupational safety. It has been centred on warehousing operations to create a comfortable and safe workplace environment in terms of minimizing accidents by health and safety programs (Tsang et al., 2018). Other studies focus on the associations between workplace learning / organizational climate and the health of the employees, in particular by investigating sexual harassment and workplace bullying, concluding that knowledge learning has implications on improved health (Lagrosen, 2018). Also, it was presented the implications of design choices in infographics for construction for workers' health and safety, concluding that such infographics enabled the workers to make a more global assessment of the health and safety implications (Lingard et al., 2018).

Finally, comparative studies between developing and developed regions in terms of safety performance regarding the awareness and importance of safety, cost of accidents, environmental and climatic factors which 
affect the workers, occupational safety and health regulations and their implementation, workers' well-being, safety culture and safety climate (Umar et al., 2019) have been carried out.

Another recurring research subject is the need to ascertain quality and pertinent information among general web information. The focus is on the absorption and dissemination of relevant knowledge to physicians. One suggested solution consisted of a system of interest-aware topic model (IATM), in which known higher-level interests on topics expressed by each user can be modelled in consumer health forums of user's self-reported medical conditions / topics. Then, additional techniques capture how users cope with the various symptoms belonging to the same clinical condition allowing in this way the use of recommendations for given health conditions (Halder, Kan and Sugiyama, 2017).

Social media has emerged as an influential tool in terms of sharing relevant information and ensuing dissemination. Peer-reviewed literature has proposed epidemic surveillance systems that employ social media to detect the emergence of diseases. It has unveiled the flaws of traditional document classification techniques and proposed features that represent different semantic aspects of the data, in combination with ensemble machine learning techniques to identify health-related messages amid social media data. The results disclose significant improvement in identifying health related social media content, critical in the advent of a novel disease epidemic (Tuarob et al., 2013).

The selection of important information has been central to feed health delivery systems with subsequent huge impacts on patients' care outcomes. The electronic health information management systems need to guarantee the integrity of clinical data capture and the quality of information processing. Some research has debated how issues of poor data quality and information mismanagement, impact on the clinical meeting and propose a complete description of data quality issues in eHealth (Bouamran, Mair and Tao, 2012).

The concern with electronic selection of key information has been extended to the Internet. As the Internet has become one of the main sources of consumer health information, e.g., through YouTube, it is worthy to find appropriate health videos while avoiding misleading information (e.g., herbal cures for diabetes or cancer). Some research developed algorithms for ranking the most important internet channels based on professional reviewers (Fernandez-Luque, Karlsen and Melton, 2011). This main concern has been extended as well to mobile devices as tools of information sharing. The response was based on the concept of Augmented Reality intended to make systems more usable by decreasing the need of cognitive load inherent to their use. (Magalhães, Castro and Carvalho, 2011).

Culture and social behaviour is a frequent research topic, exploring either representations, or common attitudes. The subject of ontology is largely represented on this domain. Some literature enhances the need of knowledge sharing behaviour, analysing the relationship between attitude, subjective norm, perceived behavioural control and knowledge sharing behaviour. It concluded for a positive and significant relationship between those variables in $\mathrm{HCl}$ (Mafabi et al., 2017). In the same vein, a positive relation between organizational culture and knowledge management in $\mathrm{HCl}$ has been evidenced due to the need for preservation and distribution of knowledge among collaborative individuals, being therefore essential to know the role of the actors allowing creating a common knowledge frame (Margerite, 2018).

This common understanding is often achieved by online health communities $(\mathrm{OHC})$ that become valuable platforms for patients to communicate and find support. Some research shows how OHC members share general and specific knowledge demonstrating that although personal benefits promote knowledge sharing and costs prohibit it, three factors positively impact the sharing of both general and specific knowledge: a sense of selfworth, members perceived social support, and reputation enhancement (Yan et al., 2016). Others, in turn, have focused on the physicians' attitude towards inter-organizational knowledge sharing system (IOKSS) deployment in the health sector, indicating that peers, the sector and knowledge workers, are critical factors to physicians' attitudes toward IOKSS, whereas physicians' attitudes are positively associated with their intention to share knowledge (Al-Busaidi, 2015).

In terms of Internet gathered information, it has been evidenced that the consumer's ethical evaluation impacts the business by evaluating the nutrition label through websites. There is a moderating effect of nutrition knowledge, in terms of both subjective and objective nutrition label knowledge, between health consciousness and nutrition label attitude (Sun, Huang and Chu, 2015). Conversely, other research examines delivering health 
information to the end-users via coherent conversations, instead of sharing information by the Internet. The conversational system allows the end-users to express and refine their information needs using only natural language questions or statements as input, avoiding therefore the inadequacies of current delivery mechanisms (Wong, Thangarajah and Padgham, 2011).

Other studies focus on the cultural barriers that hinder the cooperation amongst agencies that constitutes often a critical problem in crisis management. For example, the Medicins Sans Frontières (MSF) an independent, medical humanitarian organization that has been acclaimed for its efforts to respond to epidemic crisis, has been pushed to the limits in terms of knowledge and information requirements, which required reviewing is organizational culture to explore how the sharing of knowledge can be exchanged (e.g., little information or knowledge shared between countries) (Stoddart et al., 2015).

It has been substantial efforts to find out common culture. The quality of life and the condition of health cannot be analysed without taking into account the cultural conditions (Cicea , 2010). Thus, some studies have focused on the perception that an individual holds on his place in life, which depends on his culture and defines the individual's health-related quality of life. This is a medical goal to be obtained through software platforms, allowing therefore the physicians to analyse it (Gonçalves, Silveira and Rocha, 2011). Conversely, others recur to ontologies to implement electronic health records (EHRs), robust in terms of their content and intuitive in terms of their value, since ontological approaches reflect the usual ways in which people cope with the world, allowing thus to model information (Little, 2010).

Data security in terms of clinical information is deemed also as a common topic. The concerns range from timely responses to pandemics to the protection of clinical data. The present pandemic at the moment of writing is showing the astonishing pace at which infectious diseases can spread globally, and officials must be prepared to react faster and with greater intelligence gathering capabilities. However, and as shown, state-of-the-art systems for Epidemic Intelligence have not kept the pace with the growing need for more robust public health event detection. In the face of this, some propose approaches that combine aspects from different featurebased event detection methods (Fisichela et al., 2010), while others underscore the need of continuous monitoring through automated control and quality management systems (Hulstiin et al., 2011).

In addition, the ISO 9001:2000 norm can embrace these concerns, supervising the quality of a Knowledge Creation Model for occupational safety and health committees (OSHCs) and its subsequent transformation into quality information (Farouk, Richardson and Santhapparaj, 2011). Finally, other research focuses on security and protection of sensitive medical data such as Electronic Health Records (EHR) by presenting an overview of security threats in pervasive healthcare and presents a secure communication scheme that outperforms the existing schemes by decreasing transmission and storage cost (Acharya and Kumar, 2010).

Last but not least, it is worth mentioning the issue of information retrieval (e.g., during reorganization processes). Besides knowledge assimilation and dissemination, the storage of relevant knowledge is also an important issue. In this way, some highlight the importance of knowledge management during organisational reorganization and describe the approach to enable $\mathrm{HCl}$ business continuity by embedding knowledge management into informatics projects. So that corporate knowledge became retained in the system and shared with successor organizations (Leyton and Lambe, 2011).

\section{Discussion and conclusion}

In the last decade, papers on the $\mathrm{KM}$ and $\mathrm{HCl}$ topics have been published uninterruptedly on a yearly basis. 2011 shows the largest number of published works with a count of 18, followed by 8 in 2010, and 5 in 2018. The other journals or publication vehicles display anywhere between 1 to 3 articles per year. These results show that studies on KM have increased lately (growth percentage year on year since 2009 is $64 \%$, and on overall is of $9 \%$ ) in an effort to understand how $\mathrm{HCl}$ work with knowledge to develop new integrative platforms, new security processes, new shared culture and new forms of ascertain relevant health information with a view to ease interpretation in care points.

$\mathrm{KM}$ should therefore progressively be part of $\mathrm{HCl}$ strategies and of the knowledge-based economy as well, along with the rising evaluation of relevant and opportune knowledge, which may have influenced research on the $\mathrm{KM}$ in the last ten years in the health sector. lastly, health workers may be discovering the importance of KM in 
the $\mathrm{HCl}$ as their activities always involve human relations and communication. in addition to this, the implementation of KM involves sustainable core advantages that are organization-specific.

KM's contributions in health resulted in four major theme categories. The first refers to the development of KM systems in the integration and interoperability of knowledge from different sources into a single semantic platform (20 studies). It points to the need to use theoretical models and programs/software to assess KM at $\mathrm{HCl}$.

Culture and social behaviour is also cited as a recurrent theme (10 articles) in terms of knowledge sharing solution that permits exploring all available knowledge in the organization for the sharing of relevant data and their dissemination, respond to epidemics and ethically acquaint health information. In other words, it refers to the interplay between explicit and tacit knowledge.

The necessity to ascertain quality and pertinent information among general web information is represented in 6 studies, in which is appointed barriers to information collection, such as the inadequacy of equipment and flaws in messages and web services.

The need to develop information technology solutions, using KM to provide occupational safety is represented in 5 studies, in terms of protection of medical data, address gaps and detect epidemics timely.

Finally, the use of KM as a resource to secure data ( 4 articles) has been explored in terms of epidemics intelligence, monitoring and quality control, in order to better support decision making in health and support systems. Through organizational change it was explored how the knowledge was secured and stored for change and how the system's architecture was developed (one article).

Due to this LR, the decision-management processes, communication system and enculturation should cooperate towards the implementation of KM, which therefore strengthens trust in the use of these tools for decision making, within communities. The studies analysed reinforce in this way the importance of seeking scientific studies to support health practices, as well as using and transforming information into practices that can be socialized to health professionals. This process aims to make knowledge accessible to all as economic globalization, driven by information and communication technologies turns $\mathrm{KM}$ a strategic resource to $\mathrm{HCl}$.

The overall research carried out confirms as important issues those identified above that relate to Knowledge Integration and Interoperability ( 3 articles); Al in Knowledge Management Systems ( 2 articles) and Ubiquitous Technologies (3 articles).

This investigation despite using one of the most relevant databases of the academic environment, might however be considered a weakness. As a suggestion for future developments it is suggested to expand the databases to be used, namely by using research from WoS academic journals.

Finally, the four thematic categories presented lack research on KM in health in order to clarify and consolidate knowledge in the area.

\section{Acknowledgements}

We would like to express our gratitude to the Editor and the Reviewers. They offered extremely valuable suggestions or improvements. The authors were supported by the GOYCOPP Research Unit of Universidade de Aveiro and UNIDCOM, Universidade Europeia.

\section{References}

Acharya, D., and Kumar, V., 2010. A secure pervasive health care system using location dependent unicast key generation scheme. Paper presented at the International Conference on Information and Knowledge Management, Proceedings,pp. 87-90.

Al-Busaidi, K., 2015. Inter-organizational knowledge sharing system in the health sector: Physicians' perspective. International Journal of Knowledge Management, 11(3), pp. 37-54.

Allerhand, L., Youngmann, B., Yom-Tov, E., and Arkadir, D., 2018. Detecting Parkinson's disease from interactions with a search engine: is expert knowledge sufficient? Paper presented at the International Conference on Information and Knowledge Management, Proceedings, pp. 1539-1542. 
Bouamrane, M. and Mair, F., 2011. An overview of electronic health systems development and integration in scotland. Paper presented at the International Conference on Information and Knowledge Management, Proceedings, pp. 5962.

Bouamrane, M. and Tao, C., 2011. Managing interoperability and complexity inhealth systems: MIXHS'11 workshop summary. Paper presented at the International Conference on Information and Knowledge Management, Proceedings, pp. 2635-2636.

Bouamrane, M., Mair, F. S., and Tao, C., 2012. An overview of electronic health information management systems quality assessment. Paper presented at the International Conference on Information and Knowledge Management, Proceedings, pp. 37-46.

Boyd, T., Lee, B., Savel, T., Stinn, J., and Kesarinath, G., 2011. An example of the use of public health grid (PHGrid) technology during the $2009 \mathrm{H} 1 \mathrm{~N} 1$ influenza pandemic. International Journal of Grid and Utility Computing, 2(2), pp. 148-155.

Bratu, C., 2010. Health politics and systems in the european union: particularities and changes. Paper presented at the Business Transformation through Innovation and Knowledge Management: An Academic Perspective Proceedings of the 14th International Business Information Management Association Conference, IBIMA 2010, 1, pp. 153-160.

Chandra, V., and Loosemore, M., 2011. Communicating about organizational culture in the briefing process: Case study of a hospital project. Construction Management and Economics, 29(3), 223-231.

Cicea, C., Vasilescu, I., Banacu, C., and Nistor, C., 2010. Assessing the quantitative factors of healthcare services. Paper presented at the Business Transformation through Innovation and Knowledge Management: An Academic Perspective - Proceedings of the 14th International Business Information Management Association Conference, IBIMA 2010, 2. pp. 757-767.

Denyer, D. and Tranfield, T., 2009. Producing a systematic review. In D. A. Buchanan and A. Bryman (Eds.), The Sage Handbook of Organizational Research Methods. London: Sage Publications Ltd.

Dupplaw, D., Dasmahapatra, S., Hu, B., Lewis, P., and Shadbolt, N., 2009. A distributed, service-based framework for knowledge applications with multimedia. ACM Transactions on Information Systems, 27(4).

DOI: $10.1145 / 1629096.1629100$

Emerencia, A., Van Der Krieke, L., Petkov, N., and Aiello, M., 2011. Assessing schizophrenia with an interoperable architecture. Paper presented at the International Conference on Information and Knowledge Management, Proceedings, pp. 79-82.

Farouk, U. K., Richardson, S., and Santhapparaj, A. J. S., 2011. Occupational safety and health committees: A channel for knowledge creation in Malaysia? Paper presented at the Innovation and Knowledge Management: A Global Competitive Advantage - Proceedings of the 16th International Business Information Management Association Conference, IBIMA 2011, 4. pp. 2287-2300.

Fernandez-Luque, L., Karlsen, R., and Melton, G. B., 2011. HealthTrust: Trust-based retrieval of YouTube's diabetes channels. Paper presented at the International Conference on Information and Knowledge Management, Proceedings, pp. 1917-1920.

Fisichella, M., Stewart, A., Denecke, K., and Nejdl, W., 2010. Unsupervised public health event detection for epidemic intelligence. Paper presented at the International Conference on Information and Knowledge Management, Proceedings, pp. 1881-1884.

Girard, J.P., and Girard, J.L., 2015. Defining knowledge management: Toward an applied compendium, Online Journal of Applied Knowledge Management. 3(1), pp. 1-20

Gonçalves, J., Silveira, A., and Rocha, A., 2011. A platform to study the quality of life in oncology patients. International Journal of Information Systems and Change Management, 5(3), pp. 209-220.

Granovsky, S., 2001. É possível medir ciência? V. V. Nalimov pesquisa em cientometria. Cientometria 52, pp. 127-150.

Gu, D., Deng, S., Zheng, Q., Liang, C., and Wu, J., 2019. Impacts of case-based health knowledge system in hospital management: The mediating role of group effectiveness. Information and Management, 56(8) p. 103162 https://doi.org/10.1016/j.im.2019.04.005

Halder, K., Kan, M. -., and Sugiyama, K., 2017. Health forum thread recommendation using an interest aware topic model. Paper presented at the International Conference on Information and Knowledge Management, Proceedings, Part F131841, pp. 1589-1598.

Hoeschl, H.C. and Barcellos, V., 2006, August. Artificial intelligence and knowledge management. In IFIP International Conference on Artificial Intelligence in Theory and Practice (pp. 11-19). Springer, Boston, MA.

Hulstijn, J., Christiaanse, R., Bharosa, N., Schmid, F., Van Wijk, R., Janssen, M. and Tan, Y.H., 2011, June. Continuous Control Monitoring-based Regulation: a case in the meat processing industry. In International Conference on Advanced Information Systems Engineering (pp. 238-248)., Berlin, Heidelberg: Springer

Jimmy, Zuccon, G., Koopman, B., and Demartini, G., 2019. Health card retrieval for consumer health search an empirical investigation of methods. Paper presented at the International Conference on Information and Knowledge Management, Proceedings, pp. 2405-2408.

Kaivo-Oja, J., Virtanen, P., Jalonen, H. and Stenvall, J., 2015, August. The effects of the internet of things and big data to organizations and their knowledge management practices. In International Conference on Knowledge Management in Organizations (pp. 495-513). Springer, Cham. 
Koeling, R., Tate, A. R., and Carroll, J. A., 2011. Automatically estimating the incidence of symptoms recorded in GP free text notes. Paper presented at the International Conference on Information and Knowledge Management, Proceedings, pp. 43-49.

Lagrosen, S., and Lagrosen, Y., 2018. The effects of workplace learning on employee health. Paper presented at the Proceedings of the International Conference on Intellectual Capital, Knowledge Management and Organisational Learning, ICICKM, , 2018-November pp. 143-150.

Lakhdar, S., and Bouslama, N., 2010. Insight into tunisian consumers' mind-set towards healthiness in food and healthpromoting food choices. Paper presented at the Business Transformation through Innovation and Knowledge Management: An Academic Perspective - Proceedings of the 14th International Business Information Management Association Conference, IBIMA 2010, 4, pp. 2333-2359.

Layton, S., and Lambe, A., 2011. Learning before, during and after: Applying knowledge management to the nhs in times of austerity and change. Business Information Review, 28(4), pp. 236-241.

Lingard, H., Blismas, N., Harley, J., Stranieri, A., Zhang, R. P., and Pirzadeh, P., 2018. Making the invisible visible stimulating work health and safety-relevant thinking through the use of infographics in construction design. Engineering, Construction and Architectural Management, 25(1), pp. 39-61.

Little, E. (2010. Combining ontologies and cognitive engineering to innovate electronic health records. International Journal of Innovation Science, 2(1), pp. 29-38.

Lopes, P., and Oliveira, J.L., 2011. A semantic web application framework for health systems interoperability. Paper presented at the International Conference on Information and Knowledge Management, Proceedings, pp. 87-90.

Lytras, M.D., Sakkopoulos, E., and De Pablos, P.O., 2009. Semantic web and knowledge management for the health domain: State of the art and challenges for the seventh framework programme (FP7) of the european union (20072013). International Journal of Technology Management, 47(1-3), pp. 239-249.

Mafabi, S., Nasiima, S., Muhimbise, E.M., Kasekende, F., and Nakiyonga, C., 2017. The mediation role of intention in knowledge sharing behavior. VINE Journal of Information and Knowledge Management Systems, 47(2), pp. 172-193.

Magalhães, P., Castro, A., and Carvalho, C.V., 2011. Augmented reality applied to the teaching/learning environment. Paper presented at the Proceedings of the 6th Iberian Conference on Information Systems and Technologies, CISTI 2011.

Margueritte, M.M. 2018. Place du knowledge management dans les organisations de santé. Communication Et Management, 14(1), pp. 25-38.

Moher, D., Liberati, A., Tetzlaff, J., Altman, D.G. and Prisma Group, 2009. Preferred reporting items for systematic reviews and meta-analyses: the PRISMA statement. PLoS med, 6(7), p.e1000097.

Mureşan, J. D., and Ivan, M.V., 2010. Evaluative indicators of the health of the organisations of education. Paper presented at the Business Transformation through Innovation and Knowledge Management: An Academic Perspective Proceedings of the 14th International Business Information Management Association Conference, IBIMA 2010, 4. pp. 2253-2260.

Paying the price as firms edge out talent: Knowledge can be lost forever through downsizing. Anon., 2012. Development and Learning in Organisations, 26(4), pp. 31-34.

Priyatam, P.N., Vaddepally, S., and Varma, V., 2012. Domain specific search in indian languages. Paper presented at the International Conference on Information and Knowledge Management, Proceedings, pp. 23-29.

Rosário, A., 2018. Dinâmica competitiva dos grupos estratégicos do setor Bancário de retalho em Portugal (2008-2010 e 2011-2013), Ph. D. Universidade Aveiro.

Rosário, A., and Cruz, R. 2019. Determinants of Innovation in Digital Marketing, Innovation Policy and Trends in the Digital Age, Journal of Reviews on Global Economics, 8, pp.1722-1731.

Sanzogni, L., Guzman, G. and Busch, P., 2017. Artificial intelligence and knowledge management: questioning the tacit dimension. Prometheus, 35(1), pp.37-56.

Sacavém, A., Cruz, R., Sousa, M., and Rosário, A. 2019. An Integrative Literature Review on Leadership Models for Innovative Organizations, Innovation Policy and Trends in the Digital Age, Journal of Reviews on Global Economics, 8 , pp. 1741-1751.

Stoddart, L., Madinier, H., Mazuze, J., Rey, R., and Kotlarevsky, A. 2015. Developing a knowledge strategy for medical humanitarian crises: A case study of médecins sans frontières (MSF), switzerland. Paper presented at the Proceedings of the International Conference on Intellectual Capital, Knowledge Management and Organisational Learning, ICICKM, , 2015-January, pp. 268-275.

Sun, P., Huang, H., and Chu, F., 2015. Factors instead of demographic characteristics related to nutrition label use. British Food Journal, 117(12), pp. 3024-3038.

Tao, C., Pathak, J., Welch, S.R., Bouamrane, M., Huff, S.M., and Chute, C.G., 2011. Toward semantic web based knowledge representation and extraction from electronic health records. Paper presented at the International Conference on Information and Knowledge Management, Proceedings, pp. 75-78.

Tate, A.R., Williams, T., Puri, S., Beloff, N., and Van Staa, T., 2011. Developing quality scores for electronic health records for clinical research: A study using the general practice research database. Paper presented at the International Conference on Information and Knowledge Management, Proceedings, pp. 35-41.

Taweel, A., Speedie, S., Tyson, G., Tawil, A.R.H., Peterson, K., and Delaney, B., 2011. Service and model-driven dynamic integration of health data. Paper presented at the International Conference on Information and Knowledge Management, Proceedings, pp. 11-17. 
Tsang, Y.P., Choy, K.L., Koo, P.S., Ho, G.T.S., Wu, C.H., Lam, H.Y., and Tang, V., 2018. A fuzzy association rule-based knowledge management system for occupational safety and health programs in cold storage facilities. VINE Journal of Information and Knowledge Management Systems, 48(2), pp. 199-216.

Tuarob, S., Tucker, C. S., Salathe, M., and Ram, N., 2013. Discovering health-related knowledge in social media using ensembles of heterogeneous features. Paper presented at the International Conference on Information and Knowledge Management, Proceedings, pp. 1685-1690.

Umar, T., Egbu, C., Honnurvali, M.S., Saidani, M., and Al-Bayati, A.J., 2019. Briefing: Status of occupational safety and health in GCC construction. Proceedings of Institution of Civil Engineers: Management, Procurement and Law, 172(4), pp. 137-141.

Vernadat, F.B., 2009. Enterprise integration and interoperability. In Springer handbook of automation (pp. 1529-1538). Springer, Berlin, Heidelberg.

Warkulwiz, G., Paul, L., and Mehta, K., 2014. Efficacy of knowledge transfer and exchange between CHWs and community members in low resource settings. Paper presented at the Proceedings of the 4th IEEE Global Humanitarian Technology Conference, GHTC 2014, pp. 36-40.

Willett, P., 2007. A análise bibliométrica da Revista gráfica Molecular e modelagem, oficial de Modelagem Molecular e Gráficos, 26, pp. 602-606.

Wong, W., Thangarajah, J., and Padgham, L., 2011. Health conversational system based on contextual matching of community-driven question-answer pairs. Paper presented at the International Conference on Information and Knowledge Management, Proceedings, pp. 2577-2580.

Xia, L., Zhao, M., and Qi, W., 2010. Research on the operation mechanism of EHMS. Paper presented at the Proceedings 3rd International Conference on Information Management, Innovation Management and Industrial Engineering, ICIII 2010, 2, pp. 97-100.

Yan, Z., Wang, T., Chen, Y., and Zhang, H., 2016. Knowledge sharing in online health communities: A social exchange theory perspective. Information and Management, 53(5), pp. 643-653.

Zhang, X., Yu, H., and Mu, T., 2011. Design of equipment health management information system. Paper presented at the International Conference on Management and Service Science, MASS 2011. 
Annex I: Overview of document citations period 2009 to 2019

\begin{tabular}{|c|c|c|c|c|c|c|c|c|c|c|c|c|c|}
\hline Documents & & 2009 & 2010 & 2011 & 2012 & 2013 & 2014 & 2015 & 2016 & 2017 & 2018 & 2019 & Total \\
\hline $\begin{array}{l}\text { Detecting } \\
\text { Parkinson's disease } \\
\text { from interactions } \\
\text { with a searc ... }\end{array}$ & 2018 & - & - & - & - & - & - & - & - & - & - & 1 & 1 \\
\hline $\begin{array}{l}\text { Making the } \\
\text { invisible visible } \\
\text { Stimulating work } \\
\text { health and saf... }\end{array}$ & 2018 & - & - & - & - & - & - & - & - & - & - & 2 & 2 \\
\hline $\begin{array}{l}\text { Health forum } \\
\text { thread } \\
\text { recommendation } \\
\text { using an interest } \\
\text { aware } t . . .\end{array}$ & 2017 & - & - & - & - & - & - & - & - & - & 1 & - & 1 \\
\hline $\begin{array}{l}\text { The mediation role } \\
\text { ofintention in } \\
\text { knowledge sharing } \\
\text { behavio ... }\end{array}$ & 2017 & - & - & - & - & - & - & - & - & - & 3 & 7 & 10 \\
\hline $\begin{array}{l}\text { Knowledge sharing } \\
\text { in online health } \\
\text { communities: A } \\
\text { social exc ... }\end{array}$ & 2016 & - & - & - & - & - & - & - & 2 & 12 & 26 & 49 & 89 \\
\hline $\begin{array}{l}\text { Inter- } \\
\text { organizational } \\
\text { knowledge sharing } \\
\text { system in the } \\
\text { health ... }\end{array}$ & 2015 & - & - & - & - & - & - & - & & 1 & - & - & 1 \\
\hline $\begin{array}{l}\text { Factors instead of } \\
\text { demographic } \\
\text { characteristics } \\
\text { related to nu ... }\end{array}$ & 2015 & - & - & - & - & - & - & - & 1 & - & 2 & 1 & 4 \\
\hline $\begin{array}{l}\text { Efficacy } \\
\text { ofknowledge } \\
\text { transfer and } \\
\text { exchange between } \\
\text { CHWs and ... }\end{array}$ & 2014 & - & - & - & - & - & - & - & & 1 & - & - & 1 \\
\hline $\begin{array}{l}\text { Discovering health- } \\
\text { related knowledge } \\
\text { insocial media } \\
\text { using e ... }\end{array}$ & 2013 & - & - & - & - & - & 1 & 6 & 2 & 8 & 1 & 2 & 20 \\
\hline $\begin{array}{l}\text { Domain specific } \\
\text { search in indian } \\
\text { languages }\end{array}$ & 2012 & - & - & - & - & - & 1 & 1 & - & 1 & 1 & 1 & 5 \\
\hline $\begin{array}{l}\text { An overview of } \\
\text { electronic health } \\
\text { information } \\
\text { management } \\
\text { syst... }\end{array}$ & 2012 & - & - & - & - & 2 & 2 & - & - & - & - & 1 & 5 \\
\hline $\begin{array}{l}\text { Service and } \\
\text { model-driven } \\
\text { dynamic } \\
\text { integration of } \\
\text { health data }\end{array}$ & 2011 & - & - & - & - & 5 & 2 & - & - & 1 & - & - & 8 \\
\hline $\begin{array}{l}\text { Automatically } \\
\text { estimating the } \\
\text { incidence of } \\
\text { symptoms } \\
\text { recorded ... }\end{array}$ & 2011 & - & - & - & 2 & 3 & - & - & 2 & - & - & 1 & 8 \\
\hline $\begin{array}{l}\text { A semantic web } \\
\text { application }\end{array}$ & 2011 & - & - & - & - & 1 & - & 1 & 1 & 1 & - & - & 4 \\
\hline
\end{tabular}




\begin{tabular}{|c|c|c|c|c|c|c|c|c|c|c|c|c|c|}
\hline & 2009 & 2010 & 2011 & 2012 & 2013 & 2014 & 2015 & 2016 & 2017 & 2018 & 2019 & Total \\
\hline \multicolumn{14}{|l|}{$\begin{array}{l}\text { framework for } \\
\text { health systems } \\
\text { inte ... }\end{array}$} \\
\hline $\begin{array}{l}\text { An overview of } \\
\text { electronic health } \\
\text { systems } \\
\text { development } \\
\text { \&:amp; i }\end{array}$ & 2011 & - & - & - & 1 & 3 & 3 & 1 & 1 & - & - & - & 9 \\
\hline $\begin{array}{l}\text { Assessing } \\
\text { schizophrenia } \\
\text { with an } \\
\text { interoperable } \\
\text { architecture }\end{array}$ & 2011 & - & - & - & - & 1 & - & - & - & - & - & - & 1 \\
\hline $\begin{array}{l}\text { Toward semantic } \\
\text { web based } \\
\text { knowledge } \\
\text { representation } \\
\text { and extra }\end{array}$ & 2011 & - & - & - & - & 1 & 1 & 1 & - & 3 & 1 & - & 7 \\
\hline $\begin{array}{l}\text { HealthTrust: } \\
\text { Trust-based } \\
\text { retrieval } \\
\text { ofYouTube's } \\
\text { diabetes cha ... }\end{array}$ & 2011 & - & - & - & - & 3 & 1 & - & - & 1 & - & - & 5 \\
\hline $\begin{array}{l}\text { Managing } \\
\text { interoperability } \\
\text { and complexity } \\
\text { inhealth systems: } \\
\text { M ... }\end{array}$ & 2011 & - & - & - & 1 & - & - & 1 & - & - & - & - & 2 \\
\hline $\begin{array}{l}\text { Health } \\
\text { conversational } \\
\text { system based on } \\
\text { contextual } \\
\text { matching of... }\end{array}$ & 2011 & - & - & - & 4 & - & 1 & - & - & 1 & - & - & 6 \\
\hline $\begin{array}{l}\text { A platform to } \\
\text { study the quality } \\
\text { of life in } \\
\text { oncology } \\
\text { patients }\end{array}$ & 2011 & - & - & - & - & - & - & 3 & 2 & 1 & - & 1 & 7 \\
\hline $\begin{array}{l}\text { Learning before, } \\
\text { during and after: } \\
\text { Applying } \\
\text { knowledge } \\
\text { manage }\end{array}$ & 2011 & - & - & - & 1 & - & - & - & - & - & - & - & 1 \\
\hline $\begin{array}{l}\text { Design of } \\
\text { equipment } \\
\text { health } \\
\text { management } \\
\text { information } \\
\text { system }\end{array}$ & 2011 & - & - & - & - & - & - & - & 1 & - & - & - & 1 \\
\hline $\begin{array}{l}\text { Augmented } \\
\text { reality applied to } \\
\text { the } \\
\text { teaching/learning } \\
\text { environme ... }\end{array}$ & 2011 & - & - & - & 1 & 1 & - & - & - & - & - & 2 & 4 \\
\hline $\begin{array}{l}\text { An example } \\
\text { ofthe use of } \\
\text { Public Health } \\
\text { Grid } \\
\text { (PHGrid)Technol } \\
\text {... }\end{array}$ & 2011 & - & - & - & - & - & 1 & - & - & 2 & - & - & 3 \\
\hline $\begin{array}{l}\text { Communicating } \\
\text { about }\end{array}$ & 2011 & - & - & - & 2 & 1 & 1 & 3 & 1 & 2 & 1 & 1 & 12 \\
\hline
\end{tabular}




\begin{tabular}{|c|c|c|c|c|c|c|c|c|c|c|c|c|c|}
\hline Documents & & 2009 & 2010 & 2011 & 2012 & 2013 & 2014 & 2015 & 2016 & 2017 & 2018 & 2019 & Total \\
\hline \multicolumn{14}{|l|}{$\begin{array}{l}\text { organizational } \\
\text { culture in lhe } \\
\text { briefing } p . . .\end{array}$} \\
\hline $\begin{array}{l}\text { Continuous } \\
\text { control } \\
\text { monitoring- } \\
\text { based regulation: } \\
\text { A case in th ... }\end{array}$ & 2011 & - & - & - & - & - & - & 1 & - & 1 & 1 & - & 3 \\
\hline $\begin{array}{l}\text { Unsupervised } \\
\text { public health } \\
\text { event detection } \\
\text { for epidemie inte } \\
\ldots\end{array}$ & 2010 & - & - & 1 & 3 & 4 & 5 & - & - & 1 & 3 & - & 17 \\
\hline $\begin{array}{l}\text { A secure } \\
\text { pervasive health } \\
\text { care system } \\
\text { using location } \\
\text { depende ... }\end{array}$ & 2010 & - & 2 & - & - & 1 & - & - & - & - & - & - & 3 \\
\hline $\begin{array}{l}\text { Combining } \\
\text { ontologies and } \\
\text { cognitive } \\
\text { engineering to } \\
\text { innovate e ... }\end{array}$ & 2010 & - & - & - & - & - & 1 & - & - & 1 & - & - & 2 \\
\hline $\begin{array}{l}\text { A distributed, } \\
\text { service-based } \\
\text { framework for } \\
\text { knowledge } \\
\text { applica ... }\end{array}$ & 2009 & - & - & - & 1 & 1 & - & - & - & - & - & - & 2 \\
\hline $\begin{array}{l}\text { Semantic web } \\
\text { and knowledge } \\
\text { management for } \\
\text { the health } \\
\text { domain:... }\end{array}$ & 2009 & 1 & 6 & 3 & 1 & 3 & 1 & 6 & & 1 & & 1 & 23 \\
\hline & Total & 1 & 8 & 4 & 17 & 30 & 21 & 24 & 13 & 37 & 39 & 73 & 267 \\
\hline
\end{tabular}

Source: original source.

Annex II: Overview of document self-citation period 2009 to 2019

\begin{tabular}{|c|c|c|c|c|c|c|c|c|c|c|c|c|c|}
\hline Documents & & 2009 & 2010 & 2011 & 2012 & 2013 & 2014 & 2015 & 2016 & 2017 & 2018 & 2019 & Total \\
\hline $\begin{array}{l}\text { Knowledge sharing } \\
\text { in online health } \\
\text { communities: A } \\
\text { social exc ... }\end{array}$ & 2016 & - & - & - & - & - & - & - & - & - & 1 & - & 1 \\
\hline $\begin{array}{l}\text { Discovering } \\
\text { health-related } \\
\text { knowledge insocial } \\
\text { media using e ... }\end{array}$ & 2013 & - & - & - & - & - & - & - & - & 3 & - & - & 3 \\
\hline $\begin{array}{l}\text { An overview of } \\
\text { electronic health } \\
\text { information } \\
\text { management } \\
\text { syst... }\end{array}$ & 2012 & - & - & - & - & - & 1 & - & - & - & - & - & 1 \\
\hline $\begin{array}{l}\text { Service and } \\
\text { model-driven } \\
\text { dynamic } \\
\text { integration of } \\
\text { health data }\end{array}$ & 2011 & - & - & - & - & 4 & 1 & - & - & - & - & - & 5 \\
\hline $\begin{array}{l}\text { Automatically } \\
\text { estimating the } \\
\text { incidence of }\end{array}$ & 2011 & - & - & - & - & - & 1 & - & - & - & - & - & 1 \\
\hline
\end{tabular}


Albérico Manuel Fernandes Travassos Rosário et al

\begin{tabular}{|c|c|c|c|c|c|c|c|c|c|c|c|c|c|}
\hline Documents & & 2009 & 2010 & 2011 & 2012 & 2013 & 2014 & 2015 & 2016 & 2017 & 2018 & 2019 & Total \\
\hline \multicolumn{14}{|l|}{$\begin{array}{l}\text { symptoms } \\
\text { recorded ... }\end{array}$} \\
\hline $\begin{array}{l}\text { An overview of } \\
\text { electronic health } \\
\text { systems } \\
\text { development } \\
\text { \&:amp; i. }\end{array}$ & 2011 & - & - & - & - & 2 & - & - & - & - & - & - & 2 \\
\hline $\begin{array}{l}\text { HealthTrust: } \\
\text { Trust-based } \\
\text { retrieval } \\
\text { ofYouTube's } \\
\text { diabetes cha ... }\end{array}$ & 2011 & - & - & - & - & 2 & - & - & - & - & - & - & 2 \\
\hline $\begin{array}{l}\text { An example } \\
\text { ofthe use of } \\
\text { Public Health } \\
\text { Grid } \\
\text { (PHGrid)Technol } \\
\text {... }\end{array}$ & 2011 & - & - & - & - & - & 1 & - & - & - & - & - & 1 \\
\hline $\begin{array}{l}\text { Semantic web } \\
\text { and knowledge } \\
\text { management for } \\
\text { the health } \\
\text { domain:... }\end{array}$ & 2009 & - & - & 2 & - & - & - & 2 & - & - & - & - & 4 \\
\hline & Total & - & - & 2 & - & 8 & 4 & 2 & - & 3 & 1 & - & 20 \\
\hline
\end{tabular}

